\title{
THE POLITICAL AND ECONOMIC RESULTS OF SEPTEMBER 2013
}

\author{
S.Zhavoronkov
}

In September 2013, voters cast their ballots on Russia' single voting day. The results of voting differed greatly from one region to another: in some regions, where the voting procedure had become a mere formality, United Russia managed to win from 40 to $80 \%$ of the votes cast, while in the regions where voting had been more or less competitive, this party bagged between 40 and $55 \%$ of the vote. The CPRF came in second, having gained more than $10 \%$ of the vote practically in every region, including Moscow. By contrast, the LDPR and, especially, Fair Russia suffered a decline in their electoral fortunes. Thus, Fair Russia failed to gain any seats in almost half of Russia's regional parliaments. In the Moscow mayoral election, Sergey Sobyanin narrowly won over his main contender, Aleksey Navalny, by bagging 51\% of the vote. The Opposition's relative success was very relative indeed - on the one hand, $27 \%$ of the vote gained by Navalny is a good result that can be treated with measured optimism; while on the other hand, it nevertheless represents a defeat suffered by a large margin. The RF Government adopted a new three-year budget marked by a number of spending cuts. Some of these measures, designed to trim the state budget, were long overdue, including the Government's decision to freeze the salaries of public servants and the military (which have been growing at a breakneck pace in recent years), the belt-tightening with regard to the rearmament program, and a partial tariff freeze on natural monopolies (tariffs paid by enterprises will be completely frozen, while those paid by individuals will grow at a rate below the inflation rate). On the other hand, the Government's attitude to the pension system causes concern - by reducing the funded part of labor pension and simultaneously speculating on the possibilities of altogether abolishing the pension system introduced only ten years previously, the Government undermines public confidence in its policies and renders the payment of reported wages entirely senseless.

The main political event of September 2013 was the conclusion of the electoral campaigns for the election of governors, regional parliaments and city mayors and the results of the subsequent elections - which had been held, for the first time, under the recently adopted law. According to that Law, elections should be held on the second Sunday of September. The Law has also established that Russia should have a single voting day (instead of two days - in March and September). Apparently, the endless introduction of amendments to electoral legislation (several changes have been introduced this year alone) perfectly suits the ruling party, United Russia, because it has a greater ability than any of its rivals to pool its resources and participate in elections in all Russia's regions simultaneously. At the same time, all the other political parties have clearly begun to suffer from a lack of resources and personnel - and for that reason, two voting days were more preferable to them than a single voting day.

The most intriguing aspects of the recent elections are as follows. The Moscow mayoral election was the only mayoral or gubernatorial election where a prominent opposition politician was allowed to contest polls ${ }^{1}$. This opposition hopeful was Aleksey Navalny.

1 Formally, the opposition politician Gennady Gudkov ran for Governor of Moscow Oblast, but his campaign was virtually nonexistent, and so he won less than $5 \%$ of the vote.
The other Moscow mayoral candidates were nominees of the parliamentary parties, a candidate nominated by Yabloko, and a self-nominated candidate running as an independent, Sergei Sobyanin, one of the most influential people in Russia. All the participants of the mayoral race had raised and spent millions of dollars on their campaigns. For that reason alone, the stakes were very high. A number of issues, including the counting of votes, were vitally important for all parliamentary and non-parliamentary parties - first of all, for Mikhail Prokhorov's Civic Platform, a new political party which contested elections based on party lists for the first time. The mayoral elections in the big cities including Moscow were important for yet another reason-according to the unwritten rules of the game, the office of big-city mayor is the highest public office an opposition politician has a chance of being elected to. By contrast, the gubernatorial elections were not a very interesting event. No surprises could be expected because of the unprecedented and draconian 'municipal filter'. The essence of this 'filter' is as follows: anyone who wants to run for governor must collect signatures from between 5 and 10 percent of municipal legislators or mayors, who may sign for only one candidate for governor. Moreover, signatures must be collected in three quarters of a region's municipalities. Therefore, any strong candidates can be excluded 
from gubernatorial elections, thus ensuring the victory of a candidate handpicked by the authorities.

Although the Moscow election campaign was very eye-catching, we will begin with the regional campaigns because their results en masse are more indicative of the political situation in Russia as a whole. Both United Russia and the opposition scored successes in the mayoral elections held in Russia's large cities. Bearing in mind the great inequality of resources between the ruling party and the opposition, it can be said that United Russia won in Vladivostok, Khabarovsk, Novgorod the Great, Vologda and Voronezh. In the last three cities, elections for mayoralties were hard fought, but the single-round election system helped pro-Kremlin candidates to win. By contrast, United Russia lost single-round mayoral elections in Yekaterinburg and Petrozavodsk. In Yekaterinburg, the mayoral election was won by the prominent local opposition politician Yevgeny Roizman. It is noteworthy that, if the two-round election system had not been replaced by the single-round one on the eve of the election, the ratio of votes received by the candidates for Yekaterinburg mayor (33\% - Yevgeny Roizman, 29\% - Yakov Dilin, and 20\% - State Duma member Alexander Burkov from Fair Russia) would have given the pro-Kremlin candidate a chance to win in the second round.

The results of the party-list elections to regional legislatures widely varied from one region to another. As before, United Russia scored extremely well in Chechnya (85\%), Kemerovo Oblast (86\%), Bashkiria (76\%) and Rostov Oblast (62\%). However, it should be added that voter attendance in the first two regions was unbelievably high - at the level of the recent presidential election. It is also noteworthy that in Rostov Oblast, voter attendance in Rostov-on-Don's two neighboring districts, Proletarskii and Pervomaiskii, was $47 \%$ and $75 \%$ respectively, while in different districts of Rostov Oblast it fluctuated between $22 \%$ and $79 \%$. In fact, such inconsistencies show that the elections in those regions were a sham. Therefore, their results reflect not the power of one or other political party but that of the "administrative resource", which has failed, for some reasons, to manifest itself in a number of districts. Thus, it has become evident that electoral fraud remains a reality on a massive scale in Russia as a whole, except in Moscow, where the situation has significantly improved in this respect.

United Russia achieved mediocre results (45-57\%) in Ivanovo and Ulyanovsk oblasts and in the republics of Sakha (Yakutia), Buriatia, Khakassia and Kalmykia. It bagged from $40 \%$ to $44 \%$ of the vote in the traditionally maverick Archangelsk (UR's lowest score of $40.6 \%$ ), Smolensk, Vladimir, Yaroslavl and Irkutsk oblasts, and Trans-Baikal Krai. The CPRF confirmed its position of the second most influential political party by having managed to gain seats in all regional legislatures, with the exception of Chechnya and Kemerovo Oblast. It won more than $10 \%$ of the vote in all of Russia's regions except for Chechnya, Bashkiria and Kemerovo Oblast. Its highest results were in Buriatia (19.3\%) and Irkutsk Oblast (18.8\%). Having passed the electoral threshold, the CPRF were outdone by its leftist rival, Fair Russia, only in one region, Khakassia $(12.7 \%$ and $15.9 \%$ respectively), and it was only in Khakassia that its results were lower than those of the LDPR (13.9\% and $16.9 \%$ respectively). It is noteworthy that in Moscow, in spite of the extremely robust election campaign conducted by the opposition, the CPRF candidate for mayor, Ivan Melnikov, garnered $10.6 \%$ of the vote, thus demonstrating that the Communist Party had retained some electoral support even in the capital. At the same time, the mayoral candidates nominated by the LDPR and Fair Russia performed dismally, gaining just $2.8 \%$ and $2.7 \%$ of the vote respectively.

For these two parliamentary parties, the recent elections sent an alarming signal. In half of Russia's regions, the LDPR and Fair Russia failed to pass the electoral threshold. Without taking into account the four most dubious regions where the party of power garnered the highest percentage of the votes cast, out of the remaining 12 regions, the LDPR failed to pass the $5 \%$ electoral threshold only in Kalmykia, while Fair Russia failed to do so in Irkutsk, Ulyanovsk, and Ivanovo oblasts, Khakassia and Kalmykia. Thus, Fair Russia turned to be the most vulnerable player on the electoral field - lacking a charismatic leader, it had lost its former share of the opposition electorate hotly contested by the ever increasing number of small political parties. Moreover, the bizarre behavior of Fair Russia's leadership (that party's election campaign on TV was limited to a rather strange episode when their second in command, Nikolai Levichev, assisted police in forcing entry into an apartment full of 'subversive' proNavalny agitation materials) - an act that had antagonized a lot of opposition voters and was counterproductive. At the same time, most of Fair Russia's leaders in the provinces were lackluster characters incapable of attracting enough votes at the regional level and unwilling to finance their campaigns on their own. In this respect, the LDPR fared much better than Fair Russia, because it had a huge 'core' electorate oriented to its leader, the charismatic and eclectic Vladimir Zhirinovsky. Nevertheless, the LDPR was rather painfully hurt by the fact of losing some of its share of non-partisan opposition voters.

The new political parties, including Mikhail Prokhorov's Civic Platform, had a very poor showing in the September elections. For example, Civic Platform 
failed to breach the electoral threshold in the majority of regions (apart from Kalmykia and Irkutsk Oblast), and sometimes it performed dismally, capturing just one or two percent of the vote. Its successes in the party-list municipal elections in Yakutsk and Krasnoyarsk and the fact that Yevgeny Roizman, the winner of the mayoral race in Yekaterinburg, is a member of Civic Platform, slightly improves its lame-duck image. Nevertheless, its prospects remains grim because Mikhail Prokhorov is by no means eager to finance from Moscow any electoral campaigns of his party's regional branches, while the party itself has even fewer financially independent regional leaders than any of the parliamentary parties. Prokhorov's unconvincingly explained refusal to run for Moscow mayor has devalued his previous major success of garnering $20 \%$ of Moscow's votes in the presidential election - a result recently outdone by Navalny. The political parties that managed to breach the electoral threshold in one of Russia's regions were as follows: Boris Nemtsov's and Mikhail Kasianov's RPR-Parnas (Yaroslavl Oblast); Rodina, a party unofficially patronized by Deputy Prime Minister Dmitry Rogozin (Archangelsk Oblast); Patriots of Russia, a party led by the businessman Gennady Semigin (Kalmykia); and Communists of Russia, a party organized by a group of communist activists expelled from the CPRF. These results should be seen primarily as a sign that the afore-mentioned parties are still alive. It is noteworthy that the electoral performance of member-parties of Vladimir Putin's Popular Front, Rodina and Patriots of Russia, was as lackluster as that of the other small political parties. Their results indicate that the Popular Front continues to be an ephemeral political union, while United Russia has once again proved to be a real electoral process participant.

In Moscow, where the voter turnout was 32\%, the pro-Kremlin candidate for mayor Sergei Sobyanin garnered $51 \%$ of the vote; Aleksey Navalny, nominated by the RPR-Parnas party - 27.2\%; Ivan Melnikov, nominated by the CPRF - 10.6\%; Sergey Mitrokhin, nominated by Yabloko - 3.5\%; Mikhail Degtiarev, nominated by the LDPR - 2.8\%; and Nikolai Levichev, nominated by Fair Russia $-2.7 \%$. If Sergei Sobianin had won about 30 thousand votes less than he did, there would have been a second round of voting. He was spared a run-off by the votes cast by soldiers garrisoned in Moscow - or, better say, by Russia's strange legislation provision stipulating that the right to vote in polls should be granted to all adult citizens (that is, including military servicemen) 'regardless of their place of residence'. And it is an open secret that soldiers usually vote under supervision from their superiors. However, it should be admitted that except for that 'irregularity', there appears to have been little vote tampering in anyone's favor. There was no multiple voting, and no voters were bussed around to various polling stations to repeatedly vote for one or other candidate - which is quite surprising actually, because this vote-rigging trick is hard to detect. Bearing in mind that Sobyanin was a pro-Kremlin candidate with enormous media and material resources, his election results were very weak. According to numerous sociological forecasts repeatedly published in the pro-government media and diligently spread on TV channels, the authorities had expected him to garner between 70 and $80 \%$ of the vote ${ }^{1}$. Those expectations failed to materialize for a number of reasons, including the fact that many proKremlin voters had been lulled into complacency by Sobyanin's widely publicized $70 \%$ personal approval rating in Moscow and decided to stay at home. By contrast, opposition voters had become strongly motivated and resolute, intrigued by the differences in the mayoral candidate's platforms and impressed by their robust and well funded election campaigns (although Sergey Mitrokhin and Mikhail Degtiarev campaigned on a more modest scale than the other candidates, their campaigns were visibly better funded than the average Russian election campaign). As a result, the opposition voters turned out en masse, thus breaking the downward trend in voter participation typical of all Russian elections except for presidential ones. In fact, Sobyanin had not campaigned at all - he had not participated in the 'televised debates', presenting himself as 'a man of deeds and not words' (a classical cliché in the parlance of today's officials), focused on such issues as the timely payment of pensions and wages, road building, improvement of social infrastructure, etc. However, his opponents had chosen a different election tactic. The concentrated attention on the various infrastructural and social problems plaguing the city of Moscow, that had become especially acute in the past three years, including traffic jams, illegal migrants and 'ethnic crime', exorbitantly priced housing and the skyrocketing prices of all products and services. The situation in Moscow had been aggravated by Sobyanin's pointless innovations such as obtrusive lawn care or the perpetual replacement of sidewalk tiles, or the new wave of the barbaric destruction of small-scale retail outlets in the summer of 2013. So-

1 The September election has yet another unexpected result admittedly secondary but nevertheless important - a shameful debacle for Russia's major polling agencies already disgraced by their 2011 State Duma election forecasts. The polling agencies' credibility hit rock bottom after it had turned out that their forecasts for the September 2013 elections had been massively biased in favor of the government. The polling amateurishly conducted by Navalny's volunteers had been much more accurate than the work of those vaunted professionals, resulting in almost impeccable forecasts. 
byanin had promised absolutely nothing to the electorate, and everyone had been aware of the fact that all the existing benefits (for example, the increased pensions or the building of new metro lines) had been initiated long ago, under Luzhkov. As a result, those positive factors had not been associated with Sobyanin. Aleksey Navalny's election result is rather ambiguous. On the one hand, he has come a very respectable second in a difficult mayoral race, and the hundreds of thousands of votes cast for him seem to be an excellent result for a 'non-systemic opposition' politician. This result clearly places him on the same level with mature politicians from the long-established political parties, and transforms him from a parvenu activist with a rather vague approval rating into a person generally acknowledged as a true politician. On the other hand, Navalny - unlike, for example, Roizman in Yekaterinburg - has nevertheless lost in spite of the honest vote count. Moreover, he has been defeated in Moscow, where he enjoys his highest approval rating. Moscow has about one hundred and fifty districts. Navalny has won in only one of them. Therefore it is hard to say whether or not he will soon become a candidate for president capable to defeat Vladimir Putin in a presidential race. Navalny's future electoral fortunes are also vague because of his lacking a political party of his own. Moreover, Navalny will lose his right to run in any election race if and when the guilty verdict in the KirovLes case comes into force, even if Navalny gets a suspended sentence. It is unlikely that any of his followers will be able to inherit his personal approval rating. Furthermore, Navalny has no hope of getting any large-scale organized support that could be provided to the leader of any parliamentary party. Nevertheless, the example of Navalny - as well as the previous example of Prokhorov -nshow that Russian society has great demand for new political leaders.

Faced with a worsening economic situation, the RF Government was forced to consider cutting expenditures and to reasonably admit that a continuation of the policy of ever higher government spending would be counterproductive. The RF Government approved the draft three-year budget and the socio-economic development forecast for 2014 and the planning period of 2015-2016, to be submitted to the State Duma. The Government announced that some of military expenditures would be postponed to the period after 2016, and that the salaries of military personnel and civil servants would be frozen; that current spending by government departments would be cut by $5 \%$; and that the funded component of labor pension would be slashed not to $2 \%$ but to zero for all people who had failed to transfer that part of their savings from Vneshekonombank to any other retirement fund, with the money ending up in the insurance component of the labor pension (in order to prevent this, a special application should be submitted). Spurred by the rumors that Vnesheconombank, the manager of Russia's main retirement fund known to heavily invest in the numerous image-making projects launched by the Russian government (such as Olympic games and world championships) ${ }^{1}$, was facing huge financial problems, the RF Government hinted at the possibility of introducing some strange measures resembling an initial step towards a wholesale confiscation of the funded part of labor pension. For example, it was said that the existing non-governmental pension funds should be 'audited' and 'auctioned', and that for the time being, until all of those measures are completed, their money should be seized and kept in Vneshekonombank. It should be noted that, on the one hand, the officialdom in the person of Minister of Finance Anton Siluanov have expressed doubts in the profitability of projects like the development of the BaikalAmur mainline (currently operating at less than half its full capacity) or the construction of the high-speed highway Moscow-Kazan, and called for caution. On the other hand, a number of new venturesome projects continue to be developed - for example, a new investment program that would enable Vneshekonombank to extend targeted credits to small businesses, at an interest rate of $10 \%$ per annum. It should be said that projects, in order to be credited under this program, should be worth at least 1 billion rubles - an unimaginable amount of money in the small-business community. In fact, Vnesheconombank's lending policy and the state of Russia's pension system, where it functions as a major operator, can become an acute problem very soon - in the next few years, on the eve of the new cycle of presidential and parliamentary elections - when the effect of the government's half measures such as the seizure of insurance contributions will be exhausted.

Yet another important financial measure was the curbing of the growth rates of tariffs for services provided by natural monopolies. Initially, bearing in mind that in the past ten years their growth had outpaced inflation, thus boosting the rate of inflation, the RF Government even planned to freeze them (the RF Ministry of Economic Development's project). Finally, it was decided to freeze the tariffs set for enterprises, and to permit the tariffs for households grow at an annual rate of $4.2 \%$, or at a pace $30 \%$ lower than inflation

1 Some of these projects are reputed to be financed by private businesses. However, these private businesses do so by means of credits issued to them by Vneshekonombank. As a rule, such credits are never repaid. 
( $4.2 \%$ is the base figure to be used by regional energy commissions; in reality, it can be increased).

September saw the adoption of the scandalous Law on Reforming the Russian Academy of Sciences (RAS), its draft having been introduced into the State Duma on the eve of summer holidays without any prior discussion. Essentially, the draft law had been aimed at eliminating the autonomy of RAS institutes by means of transferring their property to some (unspecified) agency (because of the absence of any normative acts, the identity and purpose of this agency are still totally vague even now, after the adoption of the Law), and devaluing of the title of academician by merging the highly prestigious RAS with the much less prestigious Academy of Agricultural Sciences and Academy of Medical Sciences. The full members of the RAS, so hated by the officialdom, would have lost their academician titles as a result of the necessity to appeal for admittance to the newly established institution (more than 70 academicians, most of them world-renown specialists in sciences and not humanities, had immediately rejected that procedure). The draft law had caused an enormous scandal, in the course of which all the experts previously known to be close to the RF Ministry of Education and Science had repudiated the initiative. In the aftermath of the scandal, Putin promised the academic community a number of concessions (his most important concession being the promise that, during the transition period, the newly-established academy would be headed by the current head of the RAS, Academician Vladimir Fortov. However, none of those concessions has been included in the recently adopted Law. The Academy's future remains firmly in the hands of the anonymous developers of normative acts from the apparatus of the RF Government and the Presidential Executive Office. The only concession on the part of the State Duma was that the Law should not apply to the Academy's Far Eastern, Siberian and Ural branches. The policy of clandestine talks with the authorities has so far been pointless, because the adoption of the current Law means that the authorities can now renege on any previously reached agreements, while their refusal to consolidate in the Law at least some of these agreements bodes ill for the future of the Academy. Although the voting power of the academic community is tiny, the authorities can seriously damage their image, including on the international arena, especially bearing in mind that over the past few years the Kremlin has repeatedly and loudly declared expansion of government support for science as one of its top priorities.

September saw two important high-level appointments. Assistant to President Putin and former Minister of Healthcare and Social Development Tatiana Golikova replaced Sergei Stepashin as head of the Audit Chamber, thus putting an end to a rather long intrigue and guesswork. The issue of her appointment had been hanging in abeyance for months for a number of reasons - first of all because Golikova herself perhaps would have preferred something else. After all, the Audit Chamber is a rather strange institution vested with the right to demand information from state agencies and companies, while at the same time having no right not only to punish them for the detected irregularities, but even to give them binding instructions. In fact, the Audit Chamber has been used in recent years mainly as a PR tool in various conflicts in government circles. Tatiana Golikova was replaced as Presidential Envoy to Abkhazia and South Ossetia by Vladislav Surkov, formerly the powerful first deputy head of the Presidential Executive Office and head of the government apparatus. Surkov's retirement from public service had lasted four months... In fact, he has become a member of the Kremlin's 'cadres reserve', which gives him some chances to climb back up again, God willing. 